УДК 582.28: 57083.13

\title{
Bioconversion of Fallen Leaves of the Poplars Filamentous Fungi \\ of the Genus Trichoderma
}

Elena V. Isaeva*, Olga O. Mamaeva and Tatyana V. Ryazanova Reshetnev Siberian State University of Science and Technology 31 Krasnoyarsky Rabochy, Krasnoyarsk, 660037, Russian

Received 24.03.2017, received in revised form 17.06.2017, accepted 12.08.2017

The paper shows the possibility of using the fallen leaves of poplar for cultivating mushrooms of the genus Trichoderma. It is established that the litter is available as a substrate for growth of filamentous fungi. In the process of microbiological conversion is possible to type the drug "Trichodermin" and humic substances. Using the fallen leaves of the poplar as raw materials for bioconversion allows to solve the problem of disposal of vegetable wastes.

Keywords: litter, leaves, poplars, fungi of the genus Trichoderma, bioconversion, chemical composition, humic substances.

DOI: $10.17516 / 1998-2836-0034$.

(C) Siberian Federal University. All rights reserved

* Corresponding author E-mail address: isaevaelena08@mail.ru 


\title{
Биоконверсия опавших листьев тополя \\ бальзамического мицелиальными грибами \\ рода Trichoderma
}

\author{
Е.В. Исаева, О.О. Мамаева, Т.В. Рязанова \\ Сибирский государственный университет науки \\ и технологий имени академика М.Ф. Решетнева \\ Россия, 660037, Красноярск, пр. «Красноярский рабочий», 31
}

Изучено влияние грибов рода Trichoderma на биоконверсию опавших листьев тополя и состав полученных биопродуктов. Установлено, что в процессе микробиологической конверсии субстрата мицелиальными грибами получается препарат типа «Триходермин» и гуминовые вещества. Использование опавших листьев тополя в качестве сырья для биоконверсии позволяет решить проблему утилизации растительных отходов.

Ключевые слова: химический состав, листья, тополь бальзамический, грибы рода Trichoderma, биоконверсия.

\section{Введение}

На текущий момент вопросы создания биологического методов контроля защиты растений, позволяющего отказаться от применения дорогостоящих пестицидов, актуальны. Введение в системы защиты растений биопрепаратов гарантирует экологическую чистоту защищаемого агроценоза и соблюдение санитарно-гигиенических требований. Появляются новые разработки, касающиеся использования грибов рода Trichoderma с целью получения биопрепаратов для защиты растений $[1,2]$.

Еще в 1932 г. [3] было отмечено, что микромицеты данного рода способны подавлять развитие фитопатогенных грибов, обеспечивая безопасность для живых растений. Это подтверждается и работами современных авторов [4, 5]. Грибы рода Trichoderma применяют для защиты ячменя и пшеницы от корневых гнилей [6]. Описаны стимулирующие действия гриба на прорастание семян хлопка, кукурузы, томатов и др. [7]. Продукты жизнедеятельности грибов рода Trichoderma способны усиливать обмен веществ у растений, увеличивать процент всхожести семян, ускорять развитие растений, повышать накопление питательных веществ [8].

Для культивирования грибов Trichoderma используют различные растительные отходы [9-12]. Так, для массовой наработки препарата поверхностным способом в разных странах мира используют отруби, солому пшеницы и сорго, зерно, торф, свекловичный жом, виноградные выжимки, шелуху подсолнечника и стебли кукурузы [2]. Доказана возможность получения триходермина путем культивирования грибов рода на целлюлозных гранулах [11].

В работе [9] биопрепарат с титром до $15 \cdot 10^{8} \mathrm{KOE} / г$ получен на вегетативной части топинамбура с использованием для биоконверсии штамма М99-9 Trichoderma aspirellum. В работе [10] 
получена новая форма биопрепарата Триходермин-6 с титром $1 \cdot 10^{9} \mathrm{KOE} / г$ на основе штамма «МГ-97/6» T. Aspirellum на отходах деревообрабатывающей промышленности, таких как одубина коры лиственницы.

Получение биопрепарата типа «Триходермин» с высоким титром спор (до $5 \cdot 10^{9} \mathrm{KOE} /$ г) возможно и на вегетативной части тополя. В работе [12] представлены результаты, свидетельствующие о том, что почки и побеги тополя являются доступным субстратом для роста мицелиальных грибов. В качестве растительного отхода для культивирования грибов рода Trichoderma могут быть использованы и листья тополя бальзамического [13].

Цель настоящей работы - изучение изменения химического состава опавших листьев тополя в результате культивирования грибами рода Trichoderma.

\section{Материалы и методы}

Объектом исследования служили опавшие листья тополя бальзамического (опад) (Populus balzamifera L.), произрастающего г. Красноярск. Сырье собирали в конце августа 2016 г., высушивали, измельчали до 2-5 мм и хранили в закрытой емкости при постоянной влажности.

Для культивирования использовались два штамма грибов рода Trichoderma: T. aspirellum (М99-9), выделенный из почв Мининского лесного питомника в 1999 г., и штамм К6-15, выделенный из древесины кедра на территории дендрария Института леса им. В.Н. Сукачева СО РАН в 2015 г., из коллекции музея штаммов СибГУ (рис. 1).

Субстраты доводили до 70\%-й влажности водой, помещали в чашки Петри и стерилизовали 30 мин под давлением $1,01 \cdot 10^{5}$ МПа в автоклаве. Затем субстрат инокулировали споровой суспензией музейных штаммов Trichoderma с титром $1 \cdot 10^{6}$ спор на 1 г субстрата. Посевы инкубировали в термостате при $28{ }^{\circ} \mathrm{C}$ в течение 21 сут. Отбор проб осуществляли на 7-е, $14-\mathrm{e}, 18$-е и 21-е сутки культивирования. Определение выхода колониеобразующих единиц (КОЕ) проводили с использованием камеры Горяева.

Исследования химического состава субстрата до и после биодеструкции проводили по методикам, принятым в химии растительного сырья $[14,15]$. Влажность сырья определя-

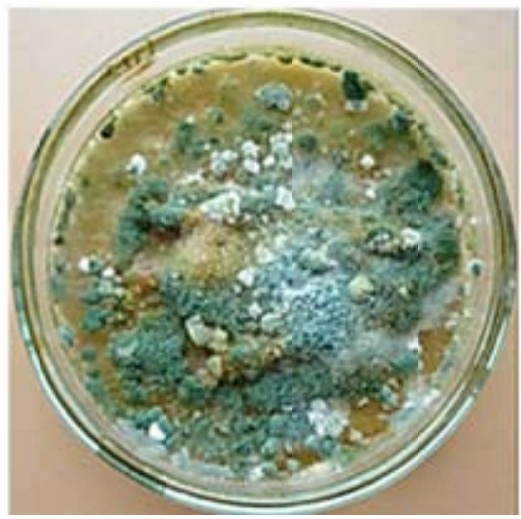

M99-9

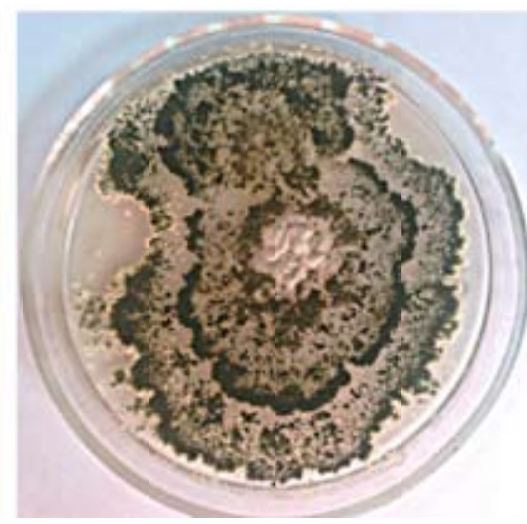

К6-15

Рис. 1. Морфология колоний исследуемых штаммов грибов рода Trichoderma на агаризованной среде

Fig. 1. Morphology of colonies of strains of fungi of the genus Trichoderma on an agar medium 
ли методом выслушивания навески сырья при $105^{\circ} \mathrm{C}$ до постоянной массы, зольные компоненты - сжиганием навески сырья с последующим прокаливанием в муфельной печи при $600^{\circ} \mathrm{C}$.

Содержание легко- и трудногидролизируемых полисахаридов определяли, применяя различные условия гидролиза минеральными кислотами. Гидролиз легкогидролизуемых полисахаридов проводили путем кипячения с $2 \%$-й соляной кислотой в течение 3 ч. Гидролиз трудногидролизуемых полисахаридов проводили $80 \%$-й серной кислотой при комнатной температуре в течение 2 ч. Массовую долю редуцирующих веществ определяли эбулиостатическим методом, основанным на принципе обратного титрования. Спиртоэкстрактивные вещества определяли с помощью исчерпывающей экстракции в аппаратах Сокслета, водоэкстрактивные - экстракции горячей водой в течение 3 ч.

Для количественного определения лигнина, как негидролизуемого остатка растительной ткани, использовали метод гидролиза $72 \%$-й серной кислотой в модификации Комарова.

Убыль массы субстрата после биодеструкции определяли весовым методом по отношению к исходному субстрату до биодеструкции.

\section{Результаты и их обсуждение}

На первом этапе работы был проведен сравнительный анализ химического состава зеленых листьев (сырье собрано 21 июля 2013 г.) и опада листьев тополя (табл. 1). Содержание компонентов рассчитано на единицу абсолютно сухого сырья (а.с.с.).

По результатам табл. 1 видно, что зеленые листья характеризуются высоким содержанием экстрактивных веществ, поскольку в них за счет процесса фотосинтеза идет образование низкомолекулярных компонентов. Количество спирто- и водорастворимых компонентов в общей доле экстрактивных веществ субстрата составляет 52 и 48 \% соответственно. В опаде количество экстрактивных веществ в 1,6 раза меньше, доля спирторастворимых компонентов составляет $14 \%$, водорастворимых - $86 \%$ от суммы этих групп веществ. Вероятно, это объясняется тем, что перед опадением листьев некоторые вещества перемещаются из них в осевые органы, в частности, почти полностью уходят из листа крахмал и сахара.

Таблица 1. Химический состав листьев тополя

Table 1. The chemical composition of poplar leaves

\begin{tabular}{|l|c|c|}
\hline \multirow{2}{*}{ Компонент } & \multicolumn{2}{c|}{ Содержание, \% а.с.с } \\
\cline { 2 - 3 } & оеленый лист & 17,4 \\
\hline Легкогидролизуемые полисахариды & 11,1 & 15,5 \\
\hline Трудногидролизуемые полисахариды & 12,3 & 32,9 \\
\hline Сумма полисахаридов & 23,4 & 20,3 \\
\hline Лигниновые вещества & 13,7 & 4,9 \\
\hline Вещества, экстрагируемые этиловым спиртом & 29,2 & 29,2 \\
\hline Вещества, экстрагируемые горячей водой & 26,7 & 34,2 \\
\hline Сумма экстрактивных веществ & 55,9 & 9,6 \\
\hline Минеральные вещества & 7,0 & \\
\hline
\end{tabular}


Для исследованных образцов установлено, что основной группой водорастворимых веществ зеленых листьев являются углеводы $-37,2 \%$ от а.с.в. экстракта. В водном экстракте опада содержание моносахаридов составило 20,2 \% от а.с.в. экстракта, на долю олигосахаридов в экстракте зеленых листьев приходится 14,9 \%, опавших - 5,9\%. Количество крахмала в зеленых листьях составляло 22 \% от суммы углеводов [16].

Содержание водорастворимого белка в зеленых листьях тополя составляет 12,3 \%. Исследования аминокислотного состава показали, что на долю незаменимых аминокислот в водорастворимом белке приходится $18 \%$. Преобладающими аминокислотами является глютаминовая и аспарагиновая кислоты, глицин, аланин (65,6 \% от суммы аминокислот) [16].

Наши исследования показали, что вещества, экстрагируемые спиртом из зеленых листьев тополя, на $4 \%$ состоят из липидов. Установлено, что на долю нейтральных приходится $53 \%$, глико- и фосфолипидов - 35 и $12 \%$ соответственно. Возможно, эти компоненты могут быть использованы в качестве дополнительного источника углеродного питания для грибов рода Trichoderma, наряду с полисахаридами и лигнином, на долю которых в зеленых листьях и опаде приходится от 37 до 53 \% веществ соответственно. Количество полисахаридов в лигноуглеводном комплексе составляет до $63 \%$.

Известно, что перед опадением листья сильно обедняются азотом, фосфором; содержание в них железа и магния почти не изменяется, количество же кальция, кремния может даже повышаться. Нами в листья тополя, как зеленых, так и опавших, установлено наличие цинка, меди, железа, марганца, кальция и других элементов, следовательно, листья тополя в процессе культивирования мицелиальных грибов могут служить источником и биогенных элементов [17].

В процессе культивирования было отмечено, что на зеленых и опавших листьях тополя процесс конидиегенеза протекал более интенсивно у штамма К6-15. Так, за 14 суток культивирования выход конидий у штаммов К6-15 и М99-9 на опаде достигал 7,12 и 4,15·10 ${ }^{8} \mathrm{KOE} /$, на субстрате из зеленых листьев - 45,6 и 23,3·10 $\mathrm{KOE} / г$ соответственно. Дальнейшее увеличение продолжительности культивирования не приводило к увеличению содержания КОЕ.

Об эффективности воздействия ферментативного комплекса грибов рода Trichoderma на субстрат судили по его убыли массы в процессе культивирования. Результаты показали, что убыль массы субстрата достигается для штамма М99-9 7,8 \% (опад) и 20,6 \% (зеленый лист), для К6-15 - 6,1 \% (опад) и 18,7 \% (зеленый лист).

Из приведенных выше результатов можно сделать вывод о том, что не только зеленые листья, но и опад тополя бальзамического может быть доступным сырьем для биодеструкции. Наиболее продуктивным при культивировании на данном субстрате является штамм T. aspirellum (К6-15).

Результаты, свидетельствующие об изменении химического состава опада после биодеструкции штаммами К6-15 и М99-9, представлены в табл. 2 и 3 соответственно. Для сравнения химического состава исходного остатка производили пересчет полученных данных с учетом коэффициента убыли массы для каждого образца в процессе культивирования грибов в течение 18-сут. Количество каждого компонента, входящего в состав субстрата, рассчитано на единицу абсолютно сухого остатка (а.с.о.).

$$
-385-
$$


Таблица2. Химический состав субстрата после биодеструкции штаммом М99-9

Table 2. Chemical composition of the substrate after biodegradation by M99-9

\begin{tabular}{|l|c|c|c|}
\hline \multirow{2}{*}{ Компонент } & \multicolumn{3}{c|}{ Содержание, \% а.с.о. } \\
\cline { 2 - 4 } & 7 сут & 14 сут & 18 сут \\
\hline Легкогидролизуемые полисахариды & 10,1 & 11,7 & 11,7 \\
\hline Трудногидролизуемые полисахариды & 10,6 & 12,4 & 15,2 \\
\hline Сумма полисахаридов & 20,7 & 14,3 & 17,8 \\
\hline Лигниновые вещества & 18,6 & 17,3 & 13,4 \\
\hline Гуминовые вещества & 20,5 & 16,6 & 3,1 \\
\hline Вещества, экстрагируемые этиловым спиртом & 4,4 & 3,5 & 26,7 \\
\hline Вещества, экстрагируемые горячей водой & 22,8 & 24,9 & 29,8 \\
\hline Сумма экстрактивных веществ & 27,2 & 28,5 & 8,4 \\
\hline Минеральные вещества & 9,0 & 8,9 & 7,5 \\
\hline Убыль массы & 3,8 & 4,6 & \\
\hline
\end{tabular}

Таблица 3. Химический состав субстрата после биодеструкции штаммом К6-15

Table 3. Chemical composition of the substrate after biodegradation by K6-15

\begin{tabular}{|l|c|c|c|}
\hline \multirow{2}{*}{\multicolumn{2}{|c|}{ Компонент }} & \multicolumn{3}{c|}{ Содержание, \% а.с.о. } \\
\cline { 2 - 4 } & 7 сут & 14 сут & 18 сут \\
\hline Легкогидролизуемые полисахариды & 10,9 & 9,6 & 10,7 \\
\hline Трудногидролизуемые полисахариды & 13,9 & 13,6 & 24,0 \\
\hline Сумма полисахаридов & 24,9 & 23,2 & 19,0 \\
\hline Лигниновые вещества & 16,7 & 16,0 & 16,1 \\
\hline Гуминовые вещества & 17,4 & 16,2 & 4,2 \\
\hline Вещества, экстрагируемые этиловым спиртом & 4,1 & 4,3 & 21,1 \\
\hline Вещества,экстрагируемые горячей водой & 23,6 & 25,0 & 25,3 \\
\hline Сумма экстрактивных веществ & 27,8 & 29,3 & 8,8 \\
\hline Минеральные вещества & 9,1 & 9,0 & 5,8 \\
\hline Убыль массы & 3,9 & 4,1 & \\
\hline
\end{tabular}

Полученные данные свидетельствуют о том, что культивирование исследуемых штаммов грибов рода Trichoderma на опаде листьев тополя приводит к изменению содержания всех компонентов субстрата.

Так, содержание легкогидролизуемых полисахаридов в субстрате на 18-е сутки культивирования штамма М99-9 снизилось на 33, а штамма К6-15 - на 39 \% по сравнению с исходным. Количество трудногидролизуемых полисахаридов в субстрате после биодеструкции штаммом К6-15 уже на 7-е сутки культивирования уменьшилось по сравнению с исходным субстратом на 10 \%, штаммом М99-9 - на 32 \%, в дальнейшем оно изменялось незначительно. Снижение содержания полисахаридов обусловлено способностью грибов рода Trichoderma образовывать целлюлолитические ферменты на природных субстратах и различных растительных отходах.

$$
-386-
$$


Содержание веществ, экстрагируемых водой, на 18-е сутки биодеструкции снизилось на 8,7 \% для штамма М99-9 и на 24 \% для штамма К6-15. Количество веществ, экстрагируемых этиловым спиртом, в процессе культивирования грибов также изменялось. Установлено, что количество липидных компонентов снизилось на 38 \%, такое изменение характерно для штамма М99-9. Этот факт подтверждает возможность использования исследуемыми штаммами грибов рода Trichoderma наряду с углеводами в качестве источника углерода и вещества липидного характера. В процессе биодеструкции опавших листьев штаммом К6-15 характерно уменьшение спиртоэкстрактивных веществ лишь на $14 \%$.

Отмечено, что в субстрате после биодеструкции происходит уменьшения количества минеральных веществ в 1,2 раза по сравнению с химическим составом субстрата до культивирования.

Таким образом, результаты показывают, что в процессе биотрансформации субстрата грибами рода Trichoderma была утилизирована основная часть полисахаридов и экстрактивных веществ. При культивировании штамма М99-9 содержание полисахаридов снизилась на 18 \%, экстрактивных веществ - на 13,2 \%, при культивировании штамма К6-15 содержание данных компонентов снизилось на 27 и $26 \%$ соответственно.

Известно, что грибы рода Trichoderma являются продуцентами лигнолитических ферментов [18]. В процессе деструкции лигноуглеводного комплекса могут образовываться гуминовые вещества. Установлено, что в процессе культивирования содержание лигниновых веществ в субстрате из опада листьев тополя снижается за первые 14 сут культивирования на 15-20\%, при этом отмечено накопление до 17 \% гуминовых веществ. Гуминовые кислоты изменяют свойства почв, оказывают прямое физиологическое воздействие на растения, стимулируют развитие корневых систем, оказывают защитное действие вредного влияния радиоактивных веществ и других загрязнителей. Поэтому полезная деятельность грибов выражается, прежде всего, в гумификации растительного сырья.

\section{Выводы}

Проведенные исследования показывают, что опавшие листья тополя являются доступным субстратом для роста мицелиальных грибов. В процессе биотрансформации грибы рода Trichoderma с большей скоростью утилизируют легкогидролизуемые полисахариды и экстрактивные веществ субстрата. Максимальное снижение содержания этих компонентов (до 40 \%) наблюдалось при использовании штамма К6-15. Получаемый на его основе биопрепарат имеет более высокий титр спор $\left(7 \cdot 10^{8} \mathrm{KOЕ} / г\right)$.

В зависимости от назначения препарата продолжительность процесса биосинтеза можно варьировать. Для получения биопрепарата типа «Триходермин» для сельского хозяйства продолжительность культивирования составляет 14 сут, для гумификации почвы 7 сут.

\section{Список литературы}

1. Алимова Ф.К. Trichoderma: таксономия и распространение. Казань: УНИПРЕССДАС, 2006. 260 c. [Alimova F.K. The Trichoderma: taxonomy and distribution. Kazan: UNIPRESS DAS, 2006. 260 p. (In Russ.)]

$$
-387-
$$


2. РГАУ-МСХА: “Использование грибов рода Trichoderma в промышленности и сельском хозяйстве" [RGAU-ICHA: "The Use of fungi of the genus Trichoderma in industry and agriculture"] [Электронный ресурс]. Режим доступа: http://www.actives-tudy.info/ispolzovanie-gribov-rodatrichoderma-v-promyshlennos-ti-i-sels-kom-xozyajstve.

3. Якименко Е.Е. Микромицеты почв лесных питомников. Микология и фитопатология. 1992. Т. 26. Вып. 6. С. 480-485. [Yakimenko E.E. Micromycetes of soils in forest nurseries. Mycology and Phytopathology. 1992. Vol. 26(6). P. 480-485. (In Russ.)]

4. Громовых Т.И. Эффективное действие Trichoderma aspirellum G. Samuels штамм МГ-97 на развитие фузариоза на сеянцах Larixibirica L. Микология и фитопатология. 2002. T. 36. Вып. 4. C. 70-75. [Gromovykh T.I. Effektivnoye deystviye Trichodermya spirellum G. Samuels shtamm MG-97 na razvitiye fuzarioza na sazhentsakh Larixibirica L. Mycology and phytopathology. 2002. Vol. 36 (4). P 70-75. (In Russ.)]

5. Трунина Т.А. Влияние Trichoderma lignorum Tode ex Harzна Fusarium oxysporum Schlecht. и F. culmorum (W.G. Sm) Sacc.в стерильной почве. Микология и фитопатология. 1982. Т. 16. Вып. 6. С. 536-538. [Trunina T.A. Effect of Trichoderma lignorum Tode ex Harz on Fusarium oxysporum Schlecht. and F. culmorum (W. G. Sm) Sacc. in the sterile soil. Mycology and Phytopathology. 1982. Vol. 16 (6). P. 536-538. (In Russ.)]

6. Кривощекова Т.Г., Мищенко В.С. Эффективность триходермина. Защита растений. 1990. № 11. C. 22. [Krivoshchekova T. G., Mishchenko V. S. Efficiency of Trichoderma. Protection of plants.1990. No. 11. P. 22. (In Russ.)]

7. Московец С.Н., Сергеев Л.А. Значение гриба Trichoderma konidii Oudem. в борьбе с болезнями сельскохозяйственных растений. Изучение и применение антибиотиков в растениеводстве: сб. ст. Ереван. 1961. С. 133-139. [Moskovets S.N., Sergeev, L.A. Significance of the fungus Trichoderma konidii Oudem. in the fight against diseases of agricultural plants. The study and application of antibiotics in plant growing: collection of articles of Yerevan. 1961. P. 133-139. (In Russ.)]

8. Гринько Н.Н., Тарасенко В.С., Стрижак Т.В. Экологически безопасная система. 3aщъита и карантин растений. 1996. № 1. C. 42-43. [Grinko N.N., Tarasenko V.S., Strizhak T.V. Ecologicallysafe system. Protection and quarantine of plants. 1996. No. 1. P. 42-43. (In Russ.)]

9. Рязанова Т.В., Чупрова А.Н., Литовка Ю.А. Биоконверсия вегетативной части топинамбура микро - и макроскопическими грибами. Системы. Методы. Технологии. 2016. № 1 (29). C. 147-151. [Ryazanova T.V., Chuprov, A.N., Litovka Yu.A. Bioconversion of the vegetative part of Jerusalem artichoke micro - and macroscopic fungi. System. Methods. Technology. 2016. No. 1 (29). P. 147-151. (In Russ.)]

10. Махова Е.Г. Культивирование грибов рода Trichoderma на углеводных субстратах и получение биопрепарата: автореф. дисс. ... канд. техн. наук. Красноярск, 2003. 22 с. [Machova E.G. Cultivation of fungi of the genus Trichoderma on carbohydrate substrates and receipt of a biological product: abstract. diss. kand. tech. sciences. Krasnoyarsk, 2003. 22 p. (In Russ.)]

11. Геллер И.Т., Беркутова И.Б., Переверзева А.Л. Рост и развитие гриба Trichoderma harzianum на гранулированных питательных средах. Биотехнология микроорганизмов в сельском хозяйстве. М., 1989. C. 115-122. [Geller I.T., Berkutova I.B., Pereverzev A.L. the Growth and 
development of fungus Trichoderma harzianum on granular nutrient medium. Biotechnology of microorganisms in agriculture. M., 1989. P. 115-122. (In Russ.)]

12. Исаева Е.В. Комплексная переработка вегетативной части тополя бальзамического с получением биологическиактивных продуктов: автореф. дис... д-ра техн. наук: 0521.03. Красноярск, 2008. 44 с. [Isaeva E.V. Complex processing of vegetative parts of balsam poplar with obtaining biologically active products: abstract. dis... d-ratekhn. Sciences: 0521.03. Krasnoyarsk, 2008. 44 p. (In Russ.)]

13. Мамаева О.О., Исаева Е.В. Биодеструкция листьев тополя бальзамического грибами рода Trichoderma. Новые достижения в химии и химической технологии растительного сырья: материалы VII Всерос. конф. Под ред. Н.Г. Базарновой, В.И. Маркина. Барнаул, Изд-во Алт. унта, 2017. C. 407-409. [Mamaeva O.O., Isaeva E.V. Biodegradability of the leaves of the poplars by fungi of the genus Trichoderma. New advances in the chemistry and chemical engineering plant materials: materials of VII all-Russia. Conf. Under Ed. Bazarnova, V.I. Markin. Barnaul, Publishing house of Alt-University, 2017. P. 407-409. (In Russ.)]

14. Рязанова Т.В., Чупрова Н.А.,. Исаева Е.В. Химия древесины. Часть 1. Строение и свойства древесины. Экстрактивные вещества. Красноярск: СибГТУ, 2011. 160 с. [Ryazanova T.V., Chuprova N.A., Isaeva E.V. Chemistry of wood. Part 1. Structure and properties of wood. Extractives. Krasnoyarsk: SibGTU, 2011. 160 p. (In Russ.)]

15. Рязанова Т.В., Чупрова Н.А., Исаева Е.В. Химия древесины. Часть 2. Основные компоненты древесины. Красноярск: СибГТУ, 2011. 229 с. [Ryazanova T.V., Chuprova N.A., Isaeva E.V. Chemistry of wood. Part 2. The main components of wood. Krasnoyarsk: SibGTU, 2011. 229 p. (In Russ.)]

16. Найденко Е.А., Шепелева О.В., Исаева Е.В. Фракционирование углеводов листьев тополя бальзамического. Новые достижения в химии и химической технологии растительного сырья: материалы VI Всерос. конф. Барнаул. 2014. C. 247-248. [Naidenko, E.A., Chepeleva O.V., Isaeva E.V. Fractionation of the carbohydrates of the leaves of poplars. New advances in the chemistry and chemical engineering plant materials: materials of VI allRussia. conf. Barnaul. 2014. P. 247-248. (In Russ.)]

17. Исаева Е.В., Рязанова Т.В., Гаврилова Л.В. Групповой химический состав листьев тополя. Sciences of Europe. N8(8). Vol 1. P. 116-121. [Isaeva E.V., Ryazanova T.V., Gavrilova L.V. Group chemical composition of poplar leaves. Sciences of Europe. N8(8). Vol 1. P. 116-121. (In Russ.)]

18. Кочерова А.В. Скрининг микромицетов - продуцентов лигнинолитических продуцентов ферментов. Молодые ученые в решении актуальных проблем науки: сб. ст. Красноярск. 2013. T. 2. C. 49-50. [Kocherov A.V. Screening of micromycetes - producers ligninolytic producers of enzymes. Young scientists in solving actual problems of science: collection of articles of Krasnoyarsk. 2013. Vol. 2. P. 49-50. (In Russ.)] 